\title{
Health Risk Assessment of Urban Suspended Particulate Matter with Special Reference to Polycyclic Aromatic Hydrocarbons: A Review
}

\author{
Khaiwal Ravindra, Atul K. Mittal and R.Van Grieken ${ }^{1}$ \\ Department of Civil Engineering, IIT, Delhi, Hauzkhas, New Delhi-110016, India \\ ${ }^{1}$ Department of Chemistry, University of Antewerp, Belgium
}

\begin{abstract}
Airborne suspended particulate matter is an important marker of air quality. The term 'particulates' includes organic and inorganic matter, nitrogen compounds, sulphur compounds, polycyclic aromatic hydrocarbons (PAHs), several heavy metals, and radionuclides. The health risks from the 'classic' pollutants sulfur dioxide, nitrogen dioxide, ozone, carbon monoxide, and particulates have been comprehensively reviewed. Alarming levels of non-classic pollutants like the PAHs have been reported globally. PAHs have been found in placental tissues of women and in umbilical cord blood samples from newborn babies. The damaged DNA in cord blood is a indication of the fate of these pollutants in the environment. Hence, a need exists for a comprehensive investigation of the human health-related aspects of exposure to particulates and PAHs in the urban environment. This paper reviews the literature on PAHs in conjunction with particulate matter on a global perspective.
\end{abstract}

\section{KEYWORDS}

particulates, $\mathrm{PM}_{10}$, PAHs, health effects

Reprint requests to: Atul K. Mittal, Assistant Professor, Dept. of Civil Engineering, IIT, Delhi, Hauzkhas, New Delhi-110016; email: akmittal@ civil.iitd.ernet.in

\section{INTRODUCTION}

Air quality in urban areas is of great concern these days, especially in connection with human health risks. The rate of population growth continues to increase, leading to a doubling of global population by the middle of $21^{\text {st }}$ century. In parallel, the process of urbanization also continues, such that the proportion of the global population living in cities will increase from around $45 \%$ to $62 \%$ by the year 2005 , creating dense centers of anthropogenic emission.

Poor control of industrial emissions and a rapid increase in ill-maintained vehicles implies that most cities in developing countries suffer from serious outdoor air pollution. The burden of ill health caused by particulate pollution, either on its own or in combination with gaseous pollutants, is enormous. At least 500,000 premature deaths and 4 to 5 million new cases of chronic bronchitis are reported each year /1/. The increase in daily mortality shows that on a global scale, $4 \%$ to $8 \%$ of premature deaths are due to exposure to particulate matter in the ambient and indoor environment $/ 2 /$. 
In India, suspended particulate matter (SPM), defined as particles of various sizes and chemical composition, exceeded the annual mean guidelines of the World Health Organization (WHO) for 294 days in Delhi and 268 days in Kolkata. About 40,000 Indians die early every year because of air pollution-7,500 in Delhi,

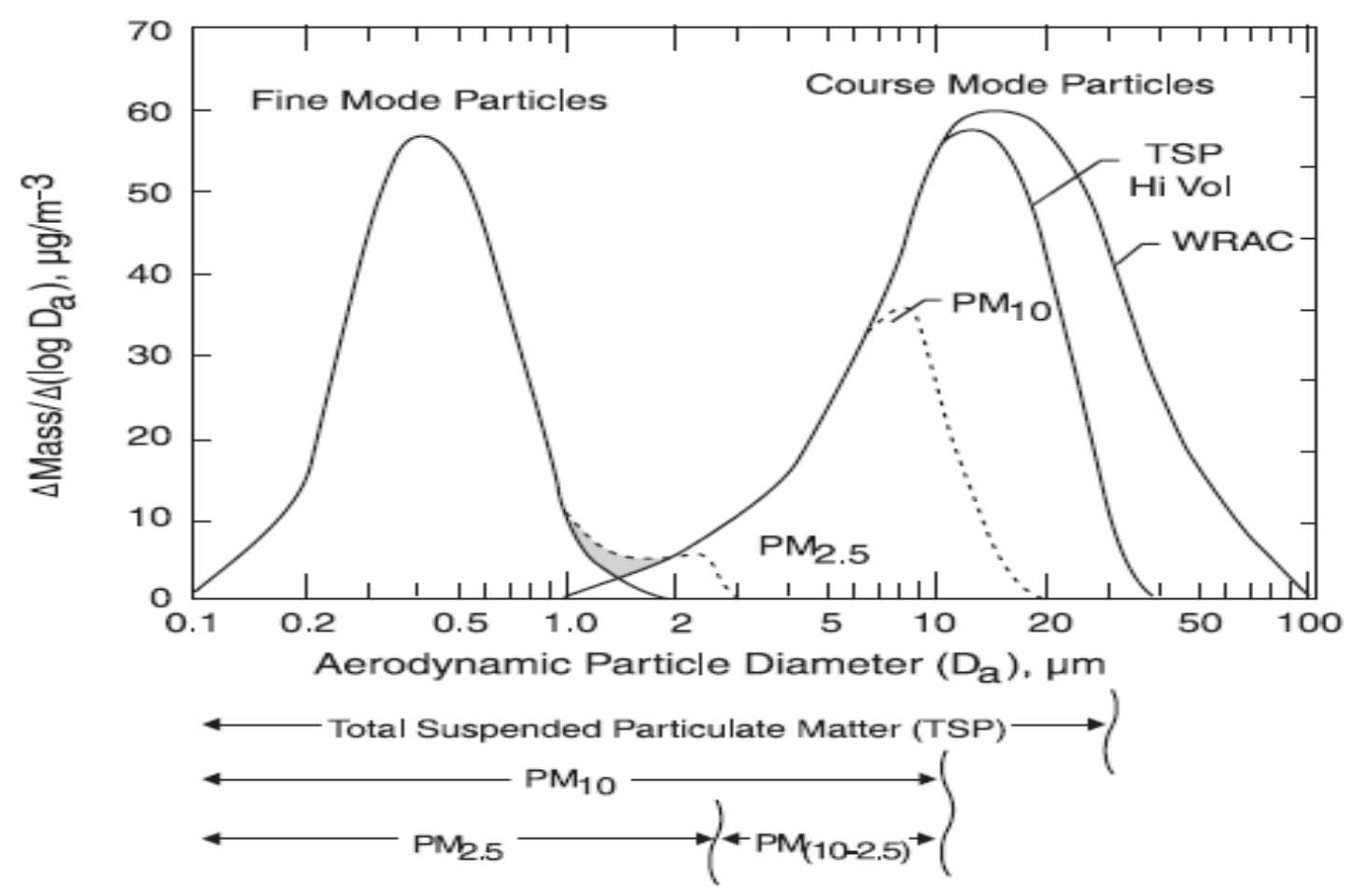

Fig 1: Representative example of mass distribution of ambient PM as function of aerodynamic particle diameter. A wide ranging of aerosol collector (WARC) provides an estimate of the full coarse mode distribution. Inlet restrictions of the high volume sampler for TSP, the PM10 sampler, and the PM2.5 sampler reduce the total mass reaching the sampler filter (source: US EPA, 1996).

4,500 in Kolkata. The World Bank estimates that Indians spend Rs. 4.55 billion every year on the treatment of diseases that are caused by ambient air pollution / $3 /$.

Indoor air pollution in developing countries is a major environmental and public health challenge. Around 50\% of people, almost all in developing countries, rely on coal and biomass in the form of wood, dung and crop residues for domestic energy. Exposure to indoor air pollution may be responsible for nearly 2 million excess deaths in developing countries and for some $4 \%$ of the global burden of disease. 


\section{PARTICULATE MATTER}

\section{Characterization}

Particulate matter varies in size, ranging from a diameter of $0.0002 \mu \mathrm{m}$ to $500 \mu \mathrm{m}$. Figure- 1 shows the size distribution of urban particulate matter /4/. Particles having an aerodynamic diameter larger than $2.5 \mu \mathrm{m}$ form the coarse particle fraction, particles having an aerodynamic diameter less than $2.5 \mu \mathrm{m}$ form the fine particle fraction, and particles having $<100 \mathrm{~nm}$ in aerodynamic diameter are classified as ultrafine particles. Table 1 presents a comparison of ambient fine and coarse mode particles /4-6/. The lifetime of particulates varies from a few seconds to several months, depending upon their settling rate, size, density of particles, and air turbulence. For example, clouds of very fine particles may drift for many miles and cause pollution at large distances from where they were emitted (Table 1).

The density of particulates in the atmosphere varies from several hundred per $\mathrm{cm}^{3}$ in clean air to more than 100,000 per $\mathrm{cm}^{3}$ in densely polluted air. In urban areas, the concentration may range from 60 to $2000 \mu \mathrm{g} / \mathrm{cm}^{3}$, whereas in remote areas, particulate content can be as low as $10 \mu \mathrm{g} / \mathrm{cm}^{3}$. Although air pollution by SPM is usually considered an urban phenomenon, in many areas of developed countries urban-rural differences in $\mathrm{PM}_{10}$ are either small or absent. Conversely, in developing countries, pollution by particulates in indoor environments is a serious problem in rural areas where biomass fuels are used for open-stove cooking and heating.

Particulate matter can be characterized by a range of different parameters, including the following:

- total mass or number concentration,

- mass or number size distribution,

- modality of size distribution,

- mass or count median diameter (MMD or CMD) of the distribution or as the mode in the distribution /7-9/.

Particulates have a large surface area and hence are attractive sites for the adsorption of various organic and inorganic matter. Air quality standards are expressed in terms of particles mass concentration as $\mathrm{PM}_{10}$ (particles below $10 \mu \mathrm{m}$ in aerodynamic diameter) or $\mathrm{PM}_{2.5}$ (particles below $10 \mu \mathrm{m}$ in aerodynamic diameter). Yet, the mechanism of toxic action of airborne particles does not inform us of whether the most important variable is particle number, surface area, or mass /10-13/. Although the number size distribution of the urban aerosol is dominated by ultrafine particles, these particles contribute very little to the total mass concentration /14/. Thus. the population of particles that is responsible for the major part of the total particle count contribute little to the mass, whereas the particles contributing most to the total mass contribute little to the total particle count /10-15/. Thus, for health risk assessment, knowledge of the particle number concentrations could be more important than knowledge of the particle mass /16-18/.

\section{TABLE 1}

Properties of ambient fine and coarse mode particles

\begin{tabular}{|l|c|c|}
\hline Property & Fine particles & Coarse particles \\
& $\left(0.1-2.5 \mu \mathrm{m}\right.$ aerodynamic diameter, $\mathrm{PM}_{2.5)}$ & $\left(2.5-10 \mu \mathrm{m}\right.$ aerodynamic diameter, $\left.\mathrm{PM}_{10}\right)$ \\
\hline
\end{tabular}




\begin{tabular}{|c|c|c|}
\hline Formed from: & Gases & Large solids/droplets \\
\hline Formed by: & $\begin{array}{l}\text { Chemical reactions; nucleation; condensation; } \\
\text { coagulation; evaporation of fog and cloud droplets in } \\
\text { which gases have dissolved and reacted }\end{array}$ & $\begin{array}{l}\text { Mechanical disruption (crushing, grinding, } \\
\text { abrasion of sprays; suspension of dusts. }\end{array}$ \\
\hline $\begin{array}{l}\text { Composition } \\
\text { (examples) }\end{array}$ & $\begin{array}{l}\text { Sulfate, nitrate; ammonium; hydrogen ion } \\
\text { Elemental carbon } \\
\text { Organic compounds (PAHs and others) } \\
\text { Heavy metals (lead, cadmium, vanadium, nickel, iron, } \\
\text { copper, zinc, manganese) } \\
\text { Particle-bound water }\end{array}$ & $\begin{array}{l}\text { Resuspended dusts (soil dusts, street dust) } \\
\text { coal and oil, fly ash, metal oxides of crystal } \\
\text { elements ( } \mathrm{Si}, \mathrm{Al}, \mathrm{Ti}, \mathrm{Fe} \text { ); } \mathrm{CaCO}_{3}, \mathrm{NaCl} \text {, sea salt; } \\
\text { pollen, mould spores; plant/animal fragments; } \\
\text { tire wear debris }\end{array}$ \\
\hline Solubility & Largely soluble, hygroscopic and deliquescent & Largely insoluble and nonhygroscopic \\
\hline Sources & $\begin{array}{l}\text { Combustion of coal, oil, gasoline, diesel, wood; } \\
\text { atmospheric transformation products of } \mathrm{NO}_{x}, \mathrm{SO}_{2} \text { and } \\
\text { organic compounds, including biogenic species } \\
\text { (terpenes, etc) high-temperature processes, smelters, } \\
\text { steel mills, and others. }\end{array}$ & $\begin{array}{l}\text { Resuspension of industrial dust and soil tracked } \\
\text { onto roads; suspension from disturbed soil } \\
\text { (farming, mining, unpaved roads, etc.); biological } \\
\text { sources; construction and demolition; coal and } \\
\text { oil combustion; ocean spray }\end{array}$ \\
\hline Lifetimes & Days to weeks & Minutes to hours \\
\hline $\begin{array}{l}\text { Travel } \\
\text { distance }\end{array}$ & Hundreds to thousands of kilometers & Less than one to tens of kilometers \\
\hline
\end{tabular}

Suspended particulate matter can be categorized into primary and secondary aerosols.

- Primary aerosols include automobile exhaust, sea spray, and dust, and are emitted into the atmosphere directly from the source.

- Secondary aerosols, generally having a diameter, $\mathrm{dp}>2.5 \mu \mathrm{m}$ are produced in the atmosphere from reactions involving primary or secondary gases.

Secondary components represent a significant fraction of both $\mathrm{PM}_{10}$ and $\mathrm{PM}_{2.5} / 19-21 /$. The dominant inorganic secondary aerosols species are sulfate, nitrate, and ammonia salts, primarily produced in a reaction of nitric acid or dinitrogen pentoxide with ammonia, sodium chloride, or dust. Sodium and chloride are also present in small quantities in the atmosphere over continental areas /19-20; 22-23/

Particulate contaminants are estimated to contain about 22 metallic elements /24/. The most abundant elements are calcium, sodium, silicon, aluminum, and iron. Considerable quantities of zinc, lead, copper, magnesium, and manganese are also present in air $/ 25 /$. Iron is one of the metals that can catalyze oxidative damage in pulmonary systems /26/. Size distribution of metals in urban aerosols in Seville, Spain has shown that potentially toxic metals, such as nickel, lead, and cadmium, accumulate mainly in smaller particles $\left(\mathrm{PM}_{2.5}\right)$, with respective percentages of $72.6,69.4$, and 63.8. The maximum concentration of lead (63.7 $\left.\mathrm{ng} / \mathrm{m}^{3}\right)$ is higher than that of copper $\left(26.7 \mathrm{ng} / \mathrm{m}^{3}\right)$, manganese $\left(16.57 \mathrm{ng} / \mathrm{m}^{3}\right)$, nickel $\left(1.977 \mathrm{ng} / \mathrm{m}^{3}\right)$, cobalt $\left(0.547 \mathrm{ng} / \mathrm{m}^{3}\right)$, or cadmium $\left(0.327 \mathrm{ng} / \mathrm{m}^{3}\right) . / 27 /$

Organic compounds found in urban areas can be classified as hydrocarbons, thiols, mercaptants, ketones, aldehydes, and polycyclic aromatic hydrocarbons, which contribute from $10 \%$ to $40 \%$ of the $\mathrm{PM}_{2.5}$ and $\mathrm{PM}_{10}$ mass in polluted urban areas. In rural areas, such compounds represent $30 \%$ to $50 \%$ of the $\mathrm{PM}_{10}$ mass $/ 19-20 /$. 
Particulate organic carbon originates from man-made activities, including petroleum residues and vehicular emissions, as well as from natural sources like plant epicular waxes and resin residues /28-31/.

\section{Polycyclic Aromatic Hydrocarbons}

The term polycyclic aromatic hydrocarbons (PAHs) covers a large group of organic compounds whose molecular structure contains two or more fused benzene rings. PAHs are widely distributed in the atmosphere, formed during the incomplete combustion of coal, oil, gas, wood, garbage, or other organic substances like tobacco and charbroiled meat. PAHs generally occur as complex mixtures like soot or environmental tobacco smoke (ETS), not as single compounds. PAHs are components of petroleum and, as such, are present in the environment from both natural and anthropogenic sources /29-33/. These pollutants are ubiquitous in ambient air, water, and soil and /29-38/. Because of their low vapor pressure, PAHs are present at ambient temperature in air, either as gases or in association with particles $/ 38,40 /$. Although certain concentrations detected in ambient air may not be directly toxic, PAHs participate in secondary chemical reactions that, in turn, produce photochemical air pollution. In Sweden, secondary harmful components like benzene and PAHs were shown to constitute a major portion of organic emissions from a recently introduced energy-efficient wood stove for residential heating and hot-water supply /39/.

The United States Agency for Toxic Substances and Disease Registry (ATSDR) ${ }^{1}$ published a toxicology profile of 17 priority PAHs (Table 2), chosen from among more than 100 different compounds because they are suspected to be more harmful than some of the others and exhibit harmful effects that are representative of the PAHs. According to the ASDSR, background levels of some representative PAHs in the air are reported to be $0.02-1.2 \mathrm{ng} / \mathrm{m}^{3}$ in rural areas and $0.15-19.3 \mathrm{ng} / \mathrm{m}^{3}$ in urban areas.

${ }^{1}$ http://www.atsdr.cdc.gov/toxprofiles/phs69.html

A. 


\section{Pericondensed}

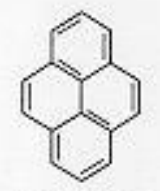

Pyrene

$\mathrm{C}_{16} \mathrm{H}_{10}$

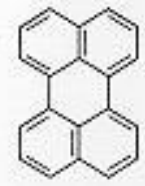

Perylene

$\mathrm{C}_{20} \mathrm{H}_{12}$

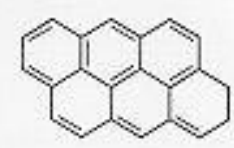

Antanthrene

$\mathrm{C}_{22} \mathrm{H}_{12}$

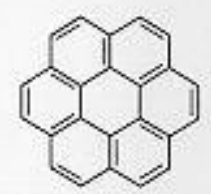

Coronene

$\mathrm{C}_{24} \mathrm{H}_{12}$

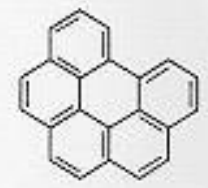

Benzo[ghi]perylene

$\mathrm{C}_{22} \mathrm{H}_{12}$

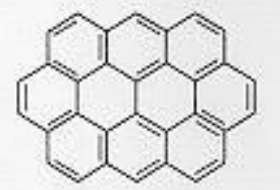

Ovalene

$\mathrm{C}_{32} \mathrm{H}_{14}$

Catacondensed

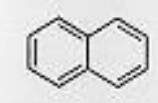

Naphthalene

$\mathrm{C}_{10} \mathrm{H}_{8}$

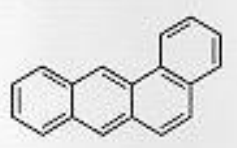

Tetraphene

$\mathrm{C}_{18} \mathrm{H}_{12}$

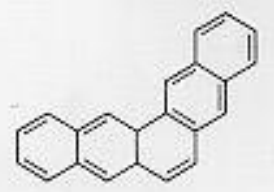

Pentaphene

$\mathrm{C}_{22} \mathrm{H}_{14}$<smiles>c1ccc2c(c1)ccc1ccccc12</smiles>

\section{Phenanthrene}

$\mathrm{C}_{14} \mathrm{H}_{10}$

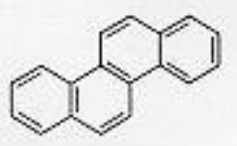

Chrysene

$\mathrm{C}_{18} \mathrm{H}_{12}$

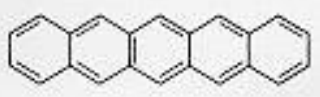

Pentacene

$\mathrm{C}_{22} \mathrm{H}_{14}$

Fig 2: Representative PAH structures. (Source: www.kepler.arc.nasa.gov/ astrochem/PAHs.jpg)

\section{Exposure Studies}

Ambient exposure. The prevalence of different PAHs in ambient air at selected sites of world are shown in Table 3 136, 41-46/. Among the most studied PAH is benzo(a)pyrene (BaP), a five ring $\left(\mathrm{C}_{20} \mathrm{H}_{12}\right)$ compound that is mutagenic for human cells in culture /47/ and carcinogenic in whole animal assays /48/. Although BaP accounts for a significant fraction of the total mutagenic activity of urban aerosol extracts, several investigators have suggested that several other PAHs may be important mutagens in urban aerosol /49-52/.

\section{TABLE 2}

ATDSR priority polycyclic aromatic hydrocarbons and their emission sources

\section{INSERT TABLE 3 HERE}

Carcinogenic PAHs are present in air as vapors or adsorbed to the surfaces of particulate matter $/ 38,53-$ 54/. The cumulative fractions of total PAHs in different particle size ranges in the ambient air of traffic intersections in Southern Taiwan and at rural sites are presented in Table 4 /55/. The results indicate that PAH exposure is widespread in Taiwan. Atmospheric concentrations of PAHs are strongly dependent upon the size of the carbon particulate matter, with the highest concentration being in the respirable size range. About $95 \%$ of total PAH is associated with a size class less than $3 \mu \mathrm{m}$ in diameter $/ 56-58 /$. 
TABLE 4

Particle size distribution of PAHs in ambient air in Taiwan

\begin{tabular}{|l|c|c|}
\hline \multirow{2}{*}{ Particle size } & \multicolumn{2}{|c|}{$\begin{array}{c}\text { Fraction of total PAH } \\
\text { (percent })\end{array}$} \\
\cline { 2 - 3 } & $\begin{array}{c}\text { Traffic } \\
\text { intersections }\end{array}$ & Rural sites \\
\hline$<1.0 \mu \mathrm{m}$ & $50.9 \%$ & $38.3 \%$ \\
\hline$<2.5 \mu \mathrm{m}$ & $74.2 \%$ & $56.4 \%$ \\
\hline$<10 \mu \mathrm{m}$ & $90.8 \%$ & 85.75 \\
\hline$<35 \mu \mathrm{m}$ & $95.9 \%$ & $94.0 \%$ \\
\hline
\end{tabular}

In several European cities, PAH levels are higher on busy urban roads than on quiet rural roads with a lower traffic density (reviewed in /59/). A recent study of PAHs in the ambient air of six towns in Northern Greece found that in the warm months, PAHs significantly correlated with vehicular pollutants, whereas during the winter the contribution of residential heating was significant $/ 60 \%$. A pilot investigation in Roxbury, Massachusetts, USA, found that both $\mathrm{PM}_{2.5}$ and PAH concentrations were greater during morning rush hours and on weekdays and significantly higher with closer proximity to the bus terminal /61/.

In Burundi, where wood combustion is used as a major energy source, mean airborne concentration of four volatile PAHs, naphthalene, fluorene, phenanthrene and acenaphthene, exceeded $1 \mu \mathrm{g} / \mathrm{m}^{3}$, and that of benzo(a)pyrene was $0.07 \mu \mathrm{g} / \mathrm{m}^{3}$. Naphthalene was by far the main PAH contaminant, with a mean concentration of $28.7 \pm 23.4 \mu \mathrm{g} / \mathrm{m}^{3}$, representing on average $60 \%$ to $70 \%$ of the total PAH concentration $/ 62 /$. In Oviedo, Spain, total concentration of PAHs in air samples analyzed by GC-MS ranged from 28 to 76 $\mathrm{ng} / \mathrm{m}^{3} / 63 /$.

In a characterization of the extent of the air toxics problem in California for the base year of 1990, risk analysis estimated a median excess individual cancer risk of 2.7E-4 for all air toxics concentrations and 8600 excess lifetime cancer cases, $70 \%$ of which were attributable to four pollutants: polycyclic organic matter, 1,3 butadiene, formaldehyde, and benzene. Although hazardous air pollutants are ubiquitous in the environment, potential cancer and noncancer health hazards posed by ambient exposures were geographically concentrated in three urbanized areas and in a few rural counties $/ 64 /$.

A Romanian study on occupational versus urban environmental air yielded surprising results. Contrary to expectations, the results showed low levels of particle-bound PAHs in the occupational environment $(<1 \mathrm{ng}$ benzo(a)pyrene $/ \mathrm{m}^{3}$ air) and high levels in urban air (range 80-1250 $\mathrm{ng}$ benzo(a)pyrene $/ \mathrm{m}^{3}$ ). The SPM collected from the power plant exhibited non-respirable characteristics (particles $>10 \mu \mathrm{m}$ ), whereas urban SPM almost exclusively contained respirable airborne particles $(<3 \mu \mathrm{m})$. The PAH burden, combined with the enhanced probability of respiratory absorption, confers a much greater hazard potential to the urban SPM. /65/

Personal exposure. The focus of air quality assessment on ambient environmental levels has ignored 
state of indoor air. Personal exposure to nine particulate-phase atmospheric PAHs was assessed among adult non-smoking volunteers in the Grenoble, France, metropolitan area, and the associated total atmospheric PAHs lifelong cancer risk was estimated. The predominant PAHs found were fluoranthene and indeno pyrene. According to the compound, the personal exposure estimates ranged from 0.13 to $1.67 \mathrm{ng} / \mathrm{m}^{3}$ (yearly means). The average benzo(a) pyrene value is $0.67 \mathrm{ng} / \mathrm{m}^{3}$ (95\% confidence interval=0 to $2.1 \mathrm{ng} / \mathrm{m}^{3}$ ). The total PAHs lung cancer lifelong risk is $7.810\left({ }^{-5}\right)$ and is driven by exposure to benzo(a) pyrene. The authors concluded that although these risk estimates are 2 to 3 orders of magnitude lower than those associated with specific occupational exposures, they are of public health concern because they are spread over large urban populations $/ 66 /$.

In Berlin, Germany, PAHs and diesel motor emission (estimated as elemental carbon (EC)) were determined in the interior of a car and in the passenger compartment of a subway train (below ground). The sampling represented a realistic exposure model for driving in a high traffic and polluted urban area. The respective mean values obtained during summer/winter inside the car were 1.0 and $3.2 \mathrm{ng} / \mathrm{m}^{3}$ for benzo[a]pyrene, 10.2 and $28.7 \mathrm{ng} / \mathrm{m}^{3}$ for total-measured-PAHs, 14.1 and $8.2 \mu \mathrm{g} / \mathrm{m}^{3}$ for EC and in the subway 0.7 and $4.0 \mathrm{ng} / \mathrm{m}^{3}$ for benzol[a]pyrene, 30.2 and $67.5 \mathrm{ng} / \mathrm{m}^{3}$ for total PAHs, 109 and $6.9 \mu \mathrm{g} / \mathrm{m}^{3}$ for EC. The significantly higher concentrations of total PAHs in the subway train were explained by the relatively high concentrations of fluoranthene and pyrene in the subway $/ 67 /$.

Environmental tobacco smoke (ETS), also called passive smoking, contains over 40 known or suspected human carcinogens, including a variety of PAHs. Passive smoking is defined as an involuntary exposure to a combined but diluted cigarette sidestream smoke (gas and particle phases that are evolved from the smoldering end of a cigarette while the smoker is not puffing) and the smoke exhaled directly from smokers (mainstream smoke). Sidestream smoke contains PAHs and other cytotoxic substances in quantities much higher than those found in mainstream smoke /68-69/. The results of a recent molecular epidemiology study in Greece demonstrated that the differences in PAH-exposure profiles of subjects exposed to relatively low levels of urban air pollution are attributable to personal individual exposure to ETS. Exposures to $\mathrm{PM}_{2.5}$ were lower in Athens (an area with moderately high levels of air pollution) during the winter than in Halkida (lower air pollution levels). Although exposures to eight particulate-bound carcinogenic PAHs were significantly higher in Athens than in Halkida, the proportion of lighter PAHs found in ETS (benzo [a]anthracene, chrysene, benzo[k]fluoranthene, and benzo[b]fluoranthene) was higher in Halkida than in Athens /70/. In Hangzhou, China, the finding that concentrations of eight PAHs in indoor air generally exceeded those in simultaneously measured outdoor air was attributed to ETS. They calculated that smoking indoors could contribute $67 \%$ of the total benzo[a]pyrene in homes /71/. Conversely, a German study in persons not occupationally exposed to PAHs found no significant difference in the PAH biomarkers between nonsmokers exposed to ETS and those not or rarely exposed to ETS /72/.

\section{HEALTH EFFECTS}

Airborne pollutants affect health in varying degrees of severity, ranging from serious illness to premature death in extreme cases. Such pollutants may produce immediate (acute), as well as long term (chronic), symptoms. Air pollution causes serious health problems, even when the levels are much lower than WHO limits $/ 2 /$. Exposure to particulate matter can aggravate chronic respiratory and cardiovascular diseases, alter 
host defenses, damage lung tissue, lead to premature death, and possibly contribute to cancer. Particle shape and size are critical factors controlling the extent to which particles can penetrate into the respiratory tract, how and where particles are deposited, and at what rate particles are cleared form respiratory tract. Furthermore, a large number of smaller particles have a greater reactive surface area than an equivalent mass of larger particles and have a higher likelihood of reaching the deepest regions of the lungs, namely the alveolar region. Ultrafine airborne particles below $1 \mu \mathrm{m}$ in diameter have been related to premature death, aggravated asthma, increased hospital admissions, and increased respiratory problems /18, 73-75/.

Most of the available information on the health effects of PAHs in humans must be inferred from studies that report the effects of exposure to complex mixtures that contain PAHs. In the environment, individuals are most likely to be exposed to PAH vapors or PAHs that are attached to dust and other particles in the air. Sources include cigarette smoke, vehicle exhausts, asphalt roads, coal, coal tar, wildfires, agricultural burning, residential wood burning, municipal and industrial waste incineration, and hazardous waste sites. Several epidemiologic studies have shown increased mortality due to lung cancer in humans exposed to coke oven emissions, roofing-tar emissions, and cigarette smoke. Each of these mixtures contains benzo[a]pyrene, chrysene, benz[a]anthracene, benzo[b]fluoranthene, and dibenz[a,h]anthracene as well as other potentially carcinogenic PAHs. ${ }^{2}$

The impacts of air pollution on health are diverse. Indicators of health impacts include the following effects:

- daily mortality (excluding accidents/suicides);

- hospital admissions on a daily basis;

- hospital emergency visits on a daily basis;

- changes in lung function on a daily basis,

- increased medication use by asthmatics;

- respiratory symptoms in children (daily diary entries);

- school and kindergarten absence;

- longitudinal survival data;

- development of asthma in longitudinal population studies, and

- cross-sectional comparison of symptoms and lung function.

The interrelationships among these indices are seldom clear, but some aggregation is possible /76-78/.

TABLE 5

Combined effect estimates of daily mean particulate pollution ${ }^{1}$

\begin{tabular}{|l|l|l|l|}
\hline Health impact & $\begin{array}{l}\text { Percent } \\
\text { change }\end{array}$ & Health impact & $\begin{array}{l}\text { Percent } \\
\text { change }\end{array}$ \\
\hline
\end{tabular}

\footnotetext{
${ }^{2}$ http://www.atsdr.cdc.gov/toxprofiles/phs69.html; Public Health Statement for Polycyclic Aromatic Hydrocarbons (PAHs).
} 


\begin{tabular}{|l|l|l|r|}
\hline Increase in daily mortality & & $\begin{array}{l}\text { Increase in respiratory symptom report } \\
\text { Lower respiratory }\end{array}$ & 3.0 \\
Total deaths & 1.0 & Upper respiratory & 0.7 \\
Respiratory deaths & 3.4 & Cough & 2.5 \\
Cardiovascular deaths & 1.4 & & \\
Increase in hospital usage & & Exacerbation of asthma & 3.0 \\
(all respiratory diagnoses & & Asthmatic attacks & 12.2 \\
Admissions & 1.4 & Bronchodilator use & 3.4 \\
Emergency department visits & 0.9 & Emergency department visit & 1 \\
Decrease in lung function & & Hospital admissions & .9 \\
Forced expiratory & 0.15 & & \\
Peak expiratory flow & 0.08 & & \\
\hline
\end{tabular}

${ }^{1}$ Percent change in health indicator per each $10 \mu \mathrm{g} / \mathrm{m}^{3}$ increase in $\mathrm{PM}_{10}$. Source: Am J Respir Crit Care Med 1996; 153: 13-50.

\section{Mortality}

Reviews and analyses of the recent epidemiological literature for acute adverse effects following exposure to particulates presented by Dockery, Pope, Schwartz, and others /79-85/ estimated these effects as percent increase in mortality associated with each incremental increase of $\mathrm{PM}_{10}$ by $10 \mu \mathrm{g} / \mathrm{m}^{3}$ (Table 5). Individuals who are elderly or have preexisting lung or heart disease appear to be more susceptible than others to the adverse effects of $\mathrm{PM}_{10}$.

TABLE 6

Comparison of daily mortality studies for selected cities

\begin{tabular}{|c|c|c|c|c|}
\hline City & $\begin{array}{l}\text { Percent } \\
\text { change } 1\end{array}$ & $\begin{array}{c}\text { Particulate matter } \\
\text { used in analysis }\end{array}$ & $\begin{array}{c}\text { Mean Daily TSP* } \\
\left(\mu \mathrm{g} / \mathrm{m}^{3}\right)\end{array}$ & Ref \\
\hline \multicolumn{5}{|l|}{ United States } \\
\hline Steubenville, $\mathrm{OH}$ & 4 & TSP(-1) & 111 & $169 /$ \\
\hline Birmingham, AL & 6 & PM10 & 87 & $/ 10 /$ \\
\hline Detroit, MI & 6 & TSP(-1) & & $\mid 671$ \\
\hline Utah Valley & 9 & PM10 (5-Days Mean) & 87 & $\mid 65 /$ \\
\hline Philadelphia, PA & 7 & TSP (2-Days Mean) & 85 & 1681 \\
\hline St. Louis, MO & 8 & PM10(-1) & 50 & $163 /$ \\
\hline Kingston/Harriman, TN & 9 & PM10(-1) & 55 & 1631 \\
\hline \multicolumn{5}{|l|}{ Europe } \\
\hline Athens, Greece & 3 (winter) & $\mathrm{BS}(-1)$ & 153 & /71/ \\
\hline Paris, France & $\begin{array}{l}4 \\
9 \\
\end{array}$ & $\begin{array}{c}\ln (\mathrm{BS}) \\
\operatorname{Ln}(\mathrm{PM} 13)\end{array}$ & $\begin{array}{l}58 \\
93 \\
\end{array}$ & $172 /$ \\
\hline Erfurt, Germany & 7 & $\operatorname{Ln}(B S)$ & 106(median) & $173 /$ \\
\hline Barcelona, Spain & 4 & BS & 64-914 (median) & /74/) \\
\hline \multicolumn{5}{|l|}{ Developing countries } \\
\hline Santiago, Chile & 4 & $\operatorname{Ln}(\mathrm{PM} 10)$ & 210 & $175 /$ \\
\hline Bankok, Thailand & 6 & PM10 (-3) & 118 & $\mid 76 /$ \\
\hline
\end{tabular}




\begin{tabular}{|l|c|c|c|c|}
\hline Beiging, China & 4 (summer) & TSP(-1) & 375 & $177 /$ \\
\hline Delhi, India & 2 & TSP(-2) & 375 & $178 /$ \\
\hline
\end{tabular}

${ }^{1}$ Daily mortality per $100 \mathrm{~g} / \mathrm{m}^{3}$ increase in TSP; $* \mathrm{PM}_{13}, \mathrm{PM}_{10}, \mathrm{Pm}_{7}$, and BS values were converted to TSP using the following relationship: $\mathrm{PM}_{13}=\mathrm{PM}_{10}=\mathrm{PM}_{7}=\mathrm{BS}=0.55 \mathrm{TSP}$

Table 6 shows the results of daily mortality studies conducted in a number of cities in the U.S., Europe, and other developing countries /79-93/. These studies found a significant and positive relation between particulate pollution and daily mortality, with an average impact on daily mortality (excluding Delhi) of $6 \%$ for a $100 \mu \mathrm{g} / \mathrm{m}^{3}$ in total suspended particles (TSP). In Delhi, the increase in TSP is associated with a $2.3 \%$ increase in deaths /93/. The results of sequential studies of six eastern U.S. cities indicate that the fine particle mass $\left(\mathrm{PM}_{2.5}\right)$ fraction from mobile and coal combustion sources, but not fine crustal particles, are associated with increased mortality /85, 94/. Other studies conducted by Bacharova et al. /95/ in Slovak Republic and Wojtyniak et al. /96/ in Poland did not find a significant relation between particulate pollution and daily mortality. In addition, Wojtyniak reported mixed results for four cities in his study. Conversely, Zimirou et al. 197/ reported significant respiratory deaths from particulates exposure in the city of Lyon, France.

Environmental tobacco smoke contributes to mortality from cancer and cardiac disease. Furthermore, it damagingly involves reproductive organs, the nervous system, genetic materials, and is particularly hazardous to mother and child during pregnancy and to those with a history of asthma, chronic infections, induced or earned immune deficiency, or predisposed susceptibility (reviewed in 67, 68).

\section{Respiratory Illness}

Countless respiratory problems are related to air pollution. The main pollutants that are responsible for this phenomenon are sulfur dioxide, the nitrogen oxides, ozone, and the particulates $\mathrm{PM}_{10}$, and $\mathrm{PM}_{2.5}$ /98$100 \%$

Respiratory tract infections. The results of many studies indicate that exposure to air pollutants increase respiratory morbidity in children $/ 77-78,101 /$. A rise in $\mathrm{PM}_{10}$ level by $10 \mu \mathrm{g} / \mathrm{m}^{3}$ augments the prevalence of bronchitis and chronic cough by as much as $25 \%$, as well as causing relatively smaller increases in respiratory deaths and reduced lung function /73/. An annual average rise in $\mathrm{PM}_{10}$ levels by $25 \mu \mathrm{g} / \mathrm{m}^{3}$ every year in Delhi implies an increase of $25 \%$ to $65 \%$ in bronchitis and chronic cough every year /102-103/. Consistent evidence indicates that indoor air pollution increases the risk of COPD and of acute respiratory infections in childhood, the most important cause of death among children under 5 years of age in developing countries $/ 101 /$.

A growing body of epidemiological data indicates that fine particles, either alone or as part of a complex mixture of air pollutants, increase asthmatic symptoms (for review see 175, 104/). In asthmatics, epidemiological studies generally show a positive correlation between the particulate fraction of air pollution and increased morbidity, although roles for other co-pollutants (for example, ozone) are implicated as well. A rise in $\mathrm{PM}_{10}$ by $10 \mu \mathrm{g} / \mathrm{m}^{3}$ increased asthma attacks by $3 \% / 73 /$. Experimental studies in predisposed animals and humans have shown that PAH associated with diesel exhaust particulates can modulate the immune response by increasing allergen-specific IgE synthesis and the cytokines involved in IgE synthesis. Conflicting evidence exists with regard to air pollution and asthma in humans. Studies from several countries found no association between particle exposure and exacerbation of asthma symptoms. Such discrepancies 
might be attributable to differences in methodology.

\section{Cardiopulmonary Illness}

In many parts of the world, air pollution is associated with increased mortality and morbidity rates not only for respiratory illnesses but also for cardiovascular illnesses. Epidemiological studies have shown a rather consistent relation between $\mathrm{PM}_{10}$ mass and cardiorespiratory illness, but no mechanism has been proposed that can fully explain this relation in terms of the toxic component of the aerosol /11-12/. Moreover, exactly what aspect(s) of mass, size, composition, or combination of these factors might be contributing to the observed adverse health effects is not known. Recent research has been directed toward gaining a better understanding of the composition of particle surface; one popular theory is that surface contaminants, such as transition metals, contribute toward ill health /105-107/. Another popular theory is that the physical characteristics (for example, number, size, shape, and aggregation properties) are important in producing health effects $/ 16,108 /$.

Average sulfur dioxide and $\mathrm{PM}_{10}$ levels in the USA and Europe are much lower than in many residential areas in India - for example, Delhi, Ghaziabad, Kolkata, and Ahmedabad. Certain areas in India have sulfur dioxide and particulate concentrations as high as $140 \mu \mathrm{g} / \mathrm{m}^{3}$ and $435 \mu \mathrm{g} / \mathrm{m}^{3}$, respectively $/ 102-103 /$. A rise in sulfur dioxide or $\mathrm{PM}_{10}$ increases the incidence of cardiovascular deaths by $1.5 \% / 83 /$. In Delhi, the annual increase in the average level of $\mathrm{PM}_{10}$ of $25 \mu \mathrm{g} / \mathrm{m}^{3}$ translates to a $5 \%$ rise in cardiovascular deaths every day /102-103/.

Preliminary epidemiologic evidence suggests that a systemic response to fine particle-induced pulmonary inflammation, including cytokine release and altered cardiac autonomic function, may be part of the pathophysiologic mechanisms or pathways linking particulate pollution with cardiopulmonary disease /109/. Air-pollution-associated increase in hospital admissions for cardiovascular diseases was almost doubled in subjects with concurrent respiratory infections. For chronic obstructive pulmonary disease (COPD) and pneumonia admissions, diagnosis of conduction disorders or dysrhythmias increased the risk of $\mathrm{PM}_{10}$-associated admissions. Persons with heart failure had twice the risk of $\mathrm{PM}_{10}$-induced COPD admissions., suggesting that patients with acute respiratory infections or defects in the electrical control of the heart are a risk group for particulate matter effects.

\section{Cancer}

The estimated range of lung cancer risk (upper 95\% confidence interval) from human epidemiological data is $1.3 \times 10^{-4}$ to $2.4 \times 10^{-3} \mu \mathrm{g} / \mathrm{m}^{3}$. Individuals who are exposed by breathing or skin contact for long periods to mixtures containing PAHs can develop cancer. The U.S. EPA has concluded that ETS or passive smoking, a common source of PAHs, causes lung cancer in adult nonsmokers. Recent evidence has established the uptake and metabolism by nonsmokers of three major classes of carcinogens found in ETS: aromatic amines, nitrosamines, and PAHs (reviewed in /69/).

According to an ATSDR Public Health Statement,. ${ }^{3}$ the International Agency for Research on Cancer (IARC) has determined that benz[a]anthracene and benzo[a]pyrene are probably carcinogenic to humans and that benzo[b]fluoranthene, benzo[j]fluoranthene, benzo[k]fluoranthene, and indeno[1,2,3-c,d]pyrene are

\footnotetext{
${ }^{3}$ http://www.atsdr.cdc.gov/toxprofiles/phs69.html; Public Health Statement for Polycyclic Aromatic Hydrocarbons (PAHs).
} 
possibly carcinogenic to humans. The U.S. EPA has determined that benz[a]anthracene, benzo[a]pyrene, benzo[b]fluoranthene, benzo[k]fluoranthene, chrysene, dibenz[a,h]anthracene, and indeno[1,2,3-c,d]pyrene are probable human carcinogens.

Exposure to diesel exhaust also contributes to lung cancer in humans. Diesel is the main source of PAH and particulate emissions in outdoor air /7, 29-31, 110-111/. The results of a recent study on inhaled diesel soot-adsorbed benzo[a]pyerene, a model PAH, indicate that direct absorption through the alveolar epithelium is an important route of entry into the circulation of unmetabolized PAHs $/ 112 /$. Chronic exposure to $1 \mu \mathrm{g} / \mathrm{m}^{3}$ of diesel exhaust can lead to 300 additional cases of lung cancer per million individuals $/ 113 /$. The direct effect of PAH and other mutagens is considered to be a maximum of five lung cancer cases each year per one million individuals /114/.

Occupational exposures to PAHs are strongly suspected to increase lung cancer risk. Two case-control studies in Germany, with 3,498 male cases and 3,541 male population controls, found elevated odds ratios (OR) (95\% confidence intervals (CI)) for lung cancer risk adjusted for smoking and asbestos exposure for diesel engine exhaust $(\mathrm{OR}=1.43,95 \%$ CI $1.23,1.67)$ and PAHs $(\mathrm{OR}=1.53,95 \%$ CI 1.14 , among others. $/ 115 /$.

Cancer results from alterations in cell structure (mutation) that result in abnormal and uncontrolled cell growth. Exposure to PAHs and SPM can cause cell mutation. The estimates of unit risk for several PAHs are presented in Table 6. In Washington, DC, USA, analysis of an organic extract of an airborne particle sample for human cell mutagens indicated that $\sim 20 \%$ of the total mutagenic fraction was accounted for in two fourth-order PAH-containing fractions that accounted for $\sim 3 \%$ of the total extract mass. A total of 13 PAHs were identified that accounted for $\sim 15 \%$ of total mutagenicity in the extract. Of these, the most important mutagens were cyclopental[cd] pyrene, benzo[a]pyrene, and benzo[b]fluoranthene, which respectively accounted for $\sim 7 \%, \sim 4 \%$, and $\sim 2 \%$, of the extract mutagenicity. Two previously unknown human lymphoblast mutagens, naphtha (2,1-a)pyrene and naptho(2,3-a)pyrene were also identified in the sample /49-50/.

DNA adduct formation is one indicator of genotoxicity /116/. A study in Greece found high levels of PHA-DNA adducts in non-smoking students living in the Halkida Institute campus, which has minimal urban air pollution. Conversely, students living in Athens, where personal PAHs exposures are significantly higher that those in Halkida, showed the lowest DNA adduct levels. In the group suffering minimal exposure to urban air pollution, three bio markers of exposure signaled that ETS was a significant determinant of DNA damage $/ 117 /$.

\section{Neonatal Health Hazards}

Human and experimental evidence indicates that the developing fetus may be more susceptible than the adult to the effects of certain carcinogens, including some PAHs. Factors that can modulate susceptibility include proliferation rates, detoxification capabilities, and DNA repair capacity. In India, human placenta, umbilical cord blood (UCB), maternal blood, and breast milk from mothers were analyzed for the presence of selected PAHs. Benzo(a)pyrene, dibenzo(a,c) anthracine, and chrysene were detected in all four sample types. The relatively high concentrations of all three PAHs in both UCB and breast milk samples implies that the developing fetus /newborn can be exposed to these contaminants in utero /118/. Chrysene, benz[a]anthraxcene, benzo[a]pyrene, benzo[b]fluoranthene, indeno[1,2,3c,d]pyrene, dibenz[a,h]anthracene, 
and benzo[g,h,I]perylene were also detected in placentas from 200 women in Ukraine /119/.

Analysis of UCB from 163 babies revealed that the blood DNA of each child had been damaged by PAH 1120/. Exposure to PAH and $\mathrm{PM}_{10}$ can result in the birth of babies who are 160 grams lighter and $1.04 \mathrm{~cm}$ shorter than normal. If mothers are simultaneously exposed to $100 \mu \mathrm{g} / \mathrm{m}^{3}$ of sulfur dioxide and $400 \mathrm{mg} / \mathrm{m}^{3}$ of particulates, then an average of two of every ten babies will be premature /92/.

A recent molecular epidemiologic study analyzed PAH-DNA adducts (as indicators of DNA damage from PAHs and other aromatics) and plasma cotinine (as an internal dosimeter of cigarette smoke) in paired blood samples collected at birth from Polish mothers and newborns /121/. In mother/newborn pairs from whom the blood sample was drawn concurrently (within $1 \mathrm{~h}$ of each other), levels of all of the three biomarkers were significantly higher in the newborn than in the paired maternal blood samples. The results suggest reduced detoxification capabilities and increased susceptibility of the fetus to DNA damage, especially in light of experimental evidence that transplacental exposures to PAHs are 10-fold lower than paired maternal exposures. The results have implications for risk assessment, which currently does not adequately account for sensitive subsets of populations.

Airborne lead is associated with particles in size range below $1 \mu \mathrm{m} / 122 /$. In urban areas of developing countries where most fuel is unleaded, concentrations of lead range from less then 0.1 to $1 \mu \mathrm{g} / \mathrm{m}^{3}$. Trafficrelated lead levels range between 0.3 and $1 \mu \mathrm{g} / \mathrm{m}^{3}$, with extreme annual mean values between $12-5 \mu \mathrm{g} / \mathrm{m}^{3}$ /2/. Lead is a well known cause of encephalopathy (a disease of the brain) in children, which often results in death or permanent brain damage. In children, the inhalation of lead can permanently lower IQ, damage emotional stability, cause hyperactivity and reduce the ability to concentrate /123-124/.related lead levels range between 0.3 and $1 \mu \mathrm{g} / \mathrm{m}^{3}$, with extreme annual mean values between $12-5 \mu \mathrm{g} / \mathrm{m}^{3} / 2 /$. Toxic effects of air pollution can also lead to mental problems, including anxiety and change in mood, cognition, and behavior. Toxic air pollutants also interfere with the development and adult functioning of the nervous system $/ 125 /$.

\section{TABLE 7}

Estimate of unit risks for several polycyclic aromatic hydrocarbons

\begin{tabular}{|l|c|c|}
\hline Compounds & $\begin{array}{c}\text { Relative potency range } \\
\text { compared with BaP }\end{array}$ & Unit risk $\left[\mu \mathrm{g} / \mathrm{m}^{3}\right]^{-1}$ \\
\hline Anthracene & $0.28-0.32$ & $(2.4-2.8) \times 10^{-2}$ \\
\hline Benz(a)anthracene & $0.14-0.145$ & $(1.2-1.3) \times 10^{-4}$ \\
\hline Benzo(a)pyrene & 1 & $(8.7) \times 10^{-2}$ \\
\hline Benzo(b)fluoranthene & $0.1-0141$ & $(0.87-1.2) \times 10^{-2}$ \\
\hline Benzo(j)fluoranthenecor & $0.045-0.1$ & $(0.4-0.87) \times 10^{-2}$ \\
\hline Benzo(k)fluoranthene & $0.01-0.1$ & $(8.7-87) \times 10^{-4}$ \\
\hline Chrycene & $0.001-0.10$ & $(8.7-870) \times 10^{-5}$ \\
\hline Cyclopental(cd)pyrene & $0.012-0.1$ & $(1.0-8.7) \times 10^{-3}$ \\
\hline
\end{tabular}




\begin{tabular}{|l|r|r|}
\hline Dibenzo(a,e)pyrene & 1 & $(8.7) \times 10^{-2}$ \\
\hline Dibenzo(a,c)anthracene & 0.1 & $(8.7) \times 10^{-3}$ \\
\hline Dibenzo(a,h)anthracene & $0.89-5$ & $(7.7-43.5) \times 10^{-2}$ \\
\hline Dibenzo(a,l)pyrene & 100 & $(8.7) \times 10^{-0}$ \\
\hline Dibenzo(a,e)fluoranthene & 1 & $(8.7) \times 10^{-2}$ \\
\hline Dibenzo(a,h)pyrene & $1-1.2$ & $(8.7-10.4) \times 10^{-2}$ \\
\hline Dibenzo(a,i)pyrene & 0.1 & $(8.7) \times 10^{-3}$ \\
\hline Fluoranthene & $0.001-0.010$ & $(8.7-87) \times 10^{-5}$ \\
\hline Indeno(1,2,3,-cd)pyrene & $0.067-0.232$ & $(5.8-20.2) \times 10^{-3}$ \\
\hline
\end{tabular}

Overall, the evidence presented here supports the view that suspended particulate matter (SPM) is associated with adverse health effects, depending upon the type and amount of pollutant present, the duration of exposure, and the state of health, age, and level of the person exposed. Respirable particulate matter (fine and coarse) contains high levels of carcinogenic PAHs. A World Bank study on the health effects of air pollution in Delhi reveled that SPM in Delhi alone led to the premature death of 7,491 people in 1991 and 1992. A repeat of the study for the year 1995 revealed an increase to about 10,000 in just 3 years, meaning a death rate of one person per hour due to air pollution $/ 3 /$.

\section{CONCLUSIONS}

Polycyclic aromatic hydrocarbons are found globally, both in developing and developed countries. Evaluating the contribution of any individual PAH to the total carcinogenicity of these mixtures in humans It is difficult because of the complexity of the mixtures and the presence of other carcinogens. Despite these limitations, the U.S. ATSDR has concluded that reports of this nature provide qualitative evidence of the potential for mixtures containing PAHs like benzo[a]pyrene, chrysene, benz[a]anthracene, benzo[b] fluoranthene, and dibenz[a,h]anthracene to cause cancer in humans. The presence of PAHs in placental tissue and the blood of newborn babies indicates that the chemical characteristics of airborne particles is deteriorating worldwide from the public health point of view. Hence, the prevention, control, and abatement of PAH contamination, along with particulates, have become an urgent need requiring the knowledge of the nature, source, and extent of pollution. Despite the ever increasing amount of information emerging from a wealth of individual air pollution studies, a lack of consistent environmental monitoring data on air toxics makes it difficult to assess the extent of low-level, chronic, ambient exposures to priority PAHs. Because reports on the health effects of particulates are divergent, conducting more epidemiological studies is imperative to establish and enforce preventive policies in air pollution. Indoor air pollution is a major global public health threat. Most governmental regulations and standards focus on ambient environmental levels of pollutants rather than on personal exposure. This approach fails to evaluate the state of indoor air. The existing evidence suggests, however, that the regulation of indoor air and the implementation of preventive 
measures should be put into practice.

\section{REFERENCES}

1. World Health Organization (WHO). Car Line. Environmental Health Criteria 1992; 127, Geneva.

2. World Health Organization (WHO). Guideline for air quality 2000, Geneva.

3. Brandon $\mathrm{C}$, Homman $\mathrm{K}$. The cost of inaction: valuing the economic-wide cast of environmental degradation in India. The World Bank, 17 October 1995.

4. US Environmental Protection Agency. Air quality criteria for particulate matter. Vol. 1, Research Triangle Park, North Carolina, USA: USEPA, 1996.

5. US Environmental Protection Agency. National Air Pollutant Emission Trends 1994. Report Number EPA 454/R95-014. USEPA Office of Air Quality Planning and Standards. Research Triangle Park, North Carolina, USA: USEPA, 1995.

6. US Environmental Protection Agency. Air Chief. United State Environmental Protection Agency,Washington DC, USA: USEPA, 1995.

7. Morawaska L, Bofinger ND, Kocss L, Nwankwoala A. Submicrometer and super micrometer particles from diesel vehicle emissions. Environmental Science and Technology 1998; 32(14): 2033- 2042.

8. Moravaska L, Thomas S, Jamriska M, Johnson G. The modality of particle size distributions of environmental aerosols. Atmospheric Environment 1999; 33: 4401-4411.

9. Moravaska L, JohnsonG, Ristovaski D, Agranovski V. Relation between particle mass and number for sub micrometer airborne particles. Atmospheric Environment 1999; 33: 1983-1990.

10. Harrison RM, Smith DJT, Luhana L. Source Apportionment of Atmospheric Polycyclic Aromatic Hydrocarbons collected from an Urban Location in Birmingham, U.K. Environmental Science and Technology 1996; 30: 825-832.

11. Harrison RM, Jones M, Collins G. Measurement of the physical properties of particles in urban atmosphere. Atmospheric Environment 1999; 33: 309 -321.

12. Harrison RM, Yin J. particulate matter in the atmosphere: which particle properties are important for its effect on health? . Science of Total Environment 2000; 249: 85-101.

13. Harrison M, Yin J, Mark D, Stedman J. Appleby RS, Booker J, Moorcroft S. Studies of the coarse particle (2.5-10 m) component in UK urban atmosphere. Atmospheric Environment 2001; 35; 3667-3679.

14. Jaenicke R. Tropospheric Aerosols In: (Ed) Hoffe, P.V., Aerosol-Cloud Climate Interactions. Academic Press, London 1993.

15. Waller RE. Studies on the nature of air pollution. London conference on museum climatology 1967; International Institute for Renovation of works of Art: 65-69.

16. Ferin J, Obserdoster G, Penney DP. Pulmonary retention of ultra fine and rarticles in rats. American Journal of Respiration Cell and Molecular biology 1992; 6:535-542.

17. Obserdorster G, Ferin J, Lehnert B. Correlation between particle size in vivo persistence and lung injury. Environmental Health Perspectives 1994; 102: 173-179.

18. Seaton A, MaeNee W, Donaldson K, Godden D. Particulate in air pollution and acute health effect. Lancet 1995; 345(8943): 176-178.

19. Chow JC, Waston JG, Lowenthal DH, Soloman PA, Magliano KL, Ziman SD, Richards LW. PM10 and PM2.5 composition in California Sari Joaquin valley. Aersal Science and Technology 1993a; 18: 105-128.

20. Chow JC, Watson JG, Fujita EM, Lu ZQ, Oawson DR, Ashbaugh LL. Temporal and spatial variation of PM2.5 and PM10 aerosol in the southern California air quality study. Atmospheric Environment, 1994b; 28: 2061 2080.

21. US Environmental Protection Agency. Aero-metric Information Retrieval System (AIRS, Database). PM 10 , $\mathrm{PM}_{2.5}$ data, Office of Air Quality Planning and Standards. Research Triangles Park, North Carolina, USA: US EPA, 1995. 
22. Richards LW. Comments on the oxidation of $\mathrm{NO}_{2}$ to nitrate day and night. Atmospheric Environment 1983; 17:397 -402.

23. Wolff GT. On the nature of coarse continental aerosols. Atmospheric Environment 1984; 18: 977-981.

24. Saitoh K, Sera K, Perales J, Gomez J, Garcia T, Angles, Suzuki H. Characterization of time particle component in Mexico City. Int. J. PIXE 1999p; 9(314): 387-396.

25. Sunum N, Tat CS, Viful L. Characterization of airborne particulates in Bankok urban area by neutron, activation analysis. Biol Elem. Res. 1999; 71-72: 181-187.

26. Dreher KL, Jaskot RH, Lehmann JR, Richards JH, Mches JK, Ghio A, Casta DL. Soluble transition metals mediate residual oil fly ash induced acute lung injury. Toxicol Environ. Health 1997; 50: 258- 305.

27. Esphinosa AJf, Rodriguez MT, Rosa FJB, Sanchez JCJ. Size distribution of metal in urban aerosols in Seville (Spain). Atmospheric Environment 2001; 35:2575-2600.

28. Masclet P, Mouvier G, Nikolaou K. Relative decay index and sources of cyclic aromatic hydrocarbons. Atmospheric Environment, 1986; 20:436-446

29. Rogge WF, Hildemann L, Mazurek MA, Cass GR, Simoneit BRT. Sources of fine Organic aerosol: 2 Non catalyst and catalyst - equipped automobiles and heavy-duty diesel trucks. Environmental science and Technology 1993a; 27: 636-651.

30. Rogge WF, Hildemann L, Muzurek MA, Cass GR, Simoneit BRT. Sources of fine organic aerosol: 3 road dust, fire debris and organometallic brake lining dust; road assurance and sinks. Environment Science and Technology 1993b; 27: 1982-1904.

31. Rogge WF, Hildemann L, Mazurek MA, Cass GR, Simoneit BRT. Sources of fine 10organic aerosol:4 particulate abration product from leaf surface of urban plant. Environmental Science and Technology 11993c; 27: $2700-2711$.

32. LaGoy PK, Quirk TC. Establishing generic remediation goals for the polycyclic aromatic hydrocarbons: critical issue. Environmental Health Perspectives 1994; 120(4): 348-352.

33. Halsall CJ, Caleman PJ, Davis BJ, Burnett V, Waterhouss KS, Harding - jones P, Jones KC. Polycyclic aromatic hydrocarbon in U.K. urban air. Environmental Science and Technology 1994; 2380-2386.

34. Finlayson - Pitts B, Pitts JN. Trophosperic air pollution: ozone air borne toxics and polycyclic aromatic hydrocarbons and particles. Science 1992; 276: 1045 - 1051.

35. Daisey JM, Miguel AH, Andrade JBD, Pereira PAP, Tanner RL. An over view of the Rio de Janerio aerosol characterization study. J. of Air pollution control Asst. 1978; (37): 15-23.

36. Allen JO, Dookeran MM, Smith KA, Sarofim AF. Measurement of poly cyclic aromatic hydrocarbons associated with size- segregated atmospheric aerosols in Massachusetts, Environmental Science Technology 1996; 30: 1023-1031.

37. Hsiao WLW, Mo Z-Y, Fang M, Shi X-M, Wang F. Cytotoxicity of PM 2.5 and PM 2.5-10 ambient air pollutants assessed by the MTT and the comet assays. Mutation Research / Genetic Toxicology and Environmental Mutagenesis 2000; 471: 45-55.

38. Cautrels W, Vancawenberghe K. Experiments on the distribution of organic pollutants between air borne particulate matter and the corresponding gas phase. Atmospheric Environment 1978; 12: 1133-1141.

39. Kjallstrand J, Petersson G. Phenols and aromatic hydrocarbons in chimney emissions from traditional and modern residential wood burning. Environ Technol 2001 Apr;22(4):391-395

40. Smith DJT, Harrison M. Concentration, trends and vehicle sources profiles of polynuclear aromatic hydrocartons in the U.K. Atmosphers. Atmosphenic Environment 1996; 30(4): 2513-2525.

41. Kavouras IG, Laurence J, Kautrakis P, Stephanou EG, Oyola P . Measurement of particulate aliphatic and polynuclear aromatic hydrocarbons in Santiago de Chile: source reconciliation and evaluation of sampling artifacts. Atmospheric Environment 1999; 33: 4477-4976.

42. Azevedo DA, Moreira LS, Siqueira DS. Composition of extractable organic matter in aerosols from urban areas of Rio de Janeiro city, Brazil. Atmospheric Environment 1999; 33: 4987-5001.

43. Oanh NTK, Reutergardh LB, Dung NT, Yu M.-H, Yao W-X, Co H-X. Polycyclic aromatic hydrocarbons in the airborne particulate matter at a location $40 \mathrm{~km}$ north of Bangkok, Thailand. Atmospheric Environment 2000; 34:4557-4563. 
44. Caricchia AM, Chiavarini S, Pezza M. Polycyclic aromatic hydrocarbons in the urban atmospheric particulate matter in the city of Naples (Italy). Atmospheric Environment 1999; 33: 3731-3738.

45. Tyagi SK. Methodological aspects of measuring polycyclic aromatic hydrocarbon (PAHs) in urban atmosphere. Chemical and Environmental Research 1994; 3: 165-176.

46. Panther BC, Hoper MA, Tapper NJ. A Comparison of air particulate matter and associated polycylic aromatic hydrocarbons in some tropical and temperate urban environments. Atmosperic Environment 1999; 33: 40874099.

47. Osborne MR, Crosby NT. Benzopyrenes, Cambridge University press: Cambridge 1987.

48. Cerna M, Pochmanova D, Pastorkova A, Bene I, Lenicek J, Topinka J, Binkova B. Genotoxicity of urban air pollutants in Czech Republic. Muation Research/Genetic Toxicology and Environmental Mutagenesis 2000; 469(1): 71-82.

49. Durant JL, Bushy WF, Lafleur AL, Penman BW, Crespi CL. Human cell mutagenicity of oxygenated, nitrated and unsubstituted polycyclic aromatic hydrocarbons associated with urban aerosols. Mutation ResearchGenetic Toxicology 1996; 371(3-4): 123-157.

50. Durant JL, Lajleur AL, Plummer EF, Taghzadeh K, Busby Jr WF, Thilly WG. Human lymphoblast mutagens in urban airborne particles. Environmental Science and Technology 1988; 32: 1894-1906.

51. Phousongphouang PT, Grosovsky AI, Eastmond DO, Covarrubias M, Arcy J. The genotoxicity of 3nitrobenzanthrone and the nitropyrene clactones in human lympho blasts. The Science of the Total Environment 2000; 263:47-55.

52. US Department of Health and Human Service, Public Health Services, National Toxicology Programme; 9th Report on carcinogen 2001.

53. Lyall RJ, Hooper MA, Mainwaring SJ. Polycyclic aromatic hydrocarbons in the Latrobe valley. Atmospheric Environment 1988; 22:2549-2555.

54. Allen JO, Durant JL, Dookearan NM, Taghizadeh K Plummer EF, Lafleur AL, Sorofim AF, Smoth KA. Measurement of $\mathrm{C} 24 \mathrm{H} 14$ polycyclic aromatic hydrocarbon associated with size -segregated urban Aerosol. Environmental Science and Technology 1998; 32(13): 1928-1932.

55. Sheu H-L, Lee W-J, Tsai J-H, Fan Y-Ch, Su Ch-Ch, Chao H-R. Particle size distribution of polycyclic aromatic hydrocarbon in the ambient air of a traffic intersection. Journal of Environmental science and Health 1996; 31(6): 1293-1316.

56. Baek SO, Field, RA, Goldstone ME, Kirk PW, Lester JN, Perry R. A review of atmospheric polycyclic aromatic hydrocarbons: sources, fate and behaviour. Water, Air and Soil pollution 1991; 60: 279-300.

57. Pistikopoulos P, Masclet P, Mouvier G. A receptor model a adapted to reactive species : polycyclic aromatic hydrocarbons; evaluation of source contributions in an open urban site-I. particle compounds. Atmospheric Environment 1990; 2 YA(5): 1189-1197.

58. Venkataraman C, Friedlander SK. Source resolution of fine particulate polycyclic aromatic hydrocarbons using a receptor model modified for reactivity. J. Air \& waste Manager. Assoc. 1994; 44:1103-1108.

59. van Wijnen JH, van der Zee SC. Traffic-related air pollutants: Exposure of road users and health effects on populations living near busy roads. Rev Environ Health 1998; 13: 1-26.

60. Papageorgopoulou A, Manoli E, Touloumi E, Samara C. Polycyclic aromatic hydrocarbons in the ambient air of Greek towns in relation to other atmospheric pollutants. Chemosphere 1999; 39: 2183-2199

61. Levy JI, Houseman EA, Spengler JD, Loh P, Ryan L. Fine particulate matter and polycyclic aromatic hydrocarbon concentration patterns in Roxbury, Massachusetts: a community-based gis analysis. Environ Health Perspect 2001 Apr;109(4):341-347

62. Viau C, Hakizimana G, Bouchard M. Indoor exposure to polycyclic aromatic hydrocarbons and carbon monoxide in traditional houses in Burundi. Int Arch Occup Environ Health 2000; 73: 331-338

63. Leal-Granadillo IA, Alonso JI, Sanz-Medel A. Determination of n-alkanes and polycyclic aromatic hydrocarbons in atmospheric particulate and vapour phases in Oviedo, Spain, by GC-MS. J Environ Monit 2000 Jun;2(3):218-22

64. Morello-Frosch RA, Woodruff TJ, Axelrad DA, Caldwell JC. Air toxics and health risks in California: the public health implications of outdoor concentrations. Risk Anal 2000; 20: 273-291. 
65. Branisteanu R, Aiking H. Exposure to polycyclic aromatic hydrocarbons in occupational versus urban environmental air. Int Arch Occup Environ Health 1998 Nov;71(8):533-6

66. Zmirou D, Masclet P, Boudet C, Dor F, Dechenaux J. Personal exposure to atmospheric polycyclic aromatic hydrocarbons in a general adult population and lung cancer risk assessment. J Occup Environ Med 2000; 42: 121-126.

67. Fromme H, Oddoy A, Piloty M, Krause M, Lahrz T. Polycyclic aromatic hydrocarbons (PAH) and diesel engine emission (elemental carbon) inside a car and a subway train. Sci Total Environ 1998 Jun 30;217(12):165-73

68. Nelson E. The miseries of passive smoking. Hum Exp Toxicol 2001; 20: 61-83.

69. Jinot J, Bayard S. Respiratory health effects of exposure to environmental tobacco smoke. Rev Environ Health 1996, 11: 89-100.

70. Georgiadis P, Stoikidou M, Topinka J, Kaila S, Gioka M, Katsouyanni K, Sram R, Kyrtopoulos SA. Personal exposures to $\mathrm{PM}(2.5)$ and polycyclic aromatic hydrocarbons and their relationship to environmental tobacco smoke at two locations in Greece. J Expo Anal Environ Epidemiol 2001; 11: 169-183

71. Liu Y, Zhu L, Shen X. Polycyclic aromatic hydrocarbons (PAHs) in indoor and outdoor air of Hangzhou, China. Environ Sci Technol 2001 Mar 1;35(5):840-844

72. Scherer G, Frank S, Riedel K, Meger-Kossien I, Renner T.. Biomonitoring of exposure to polycyclic aromatic hydrocarbons of non-occupationally exposed persons. Cancer Epidemiol Biomarkers Prev 2000; 9: 373-380.

73. Committes of the Environmental and Occupational Health Assembly of the American Thoracic Society. Health Effects of Outdoor air pollution. Americal Journal of Respiratory and critical care medicines 1996; 131(1): 133-150.

74. Morgan WKC, Reger RB, Tucker DM. Health effect of diesel emissions. Ann. Hyg. 1997; 41(6): 643-658.

75. Goldsmith C-A W, Kobzik L. Particulate air pollution and asthma: A review of epidemiological and biological studies. Rev Environ Health 1999; 14: 121-134.

76. Bates DV. Adverse health impacts of air pollution-continuing problems. Scand Journal Work Environ Health 1995a; 21: $405-411$.

77. Bates DV. The effect of air pollution on children. Environmental Health Perspectives 1995b; 103(6): 49-52.

78. Raizenne M, Dales R, Burnett R. Air pollution exposure and children health. Canadian Journal of Public Health 1998; 89; S43-S48.

79. Schwartz J, Dockery D. Particulate and daily mortality in Steubenville Ohio, American Journal of Epidemiology 1992b; 135(1): 1218.

80. Schwartz J. Air pollution and daily mortality in Birmingham, Alabama. American Journal of Epidemiology 1993; 137(10): 1136-1147.

81. Schwartz J, Dockery D. Particulate air pollution and daily morality in Detroit. Environment Research 1991; 56: 204-213.

82. Pope C, Schwartz J, Ransom M. Daily morality and $\mathbf{P M}_{10}$ pollution in Utah valley. Archives of Environmental Health 1992; 47(3): 211-217.

83. Schwartz J, Dockery D. Increased mortality in Philadelphia associated with daily air pollution concentrations. American Review of Respiratory Disease 1992; 145: 600-604.

84. Dockery DW, Schwartz J, Spengler D. Air pollution and daily mortality: associations with particulates and acid Aerosols. Environmental Research 1993; 59: 362-373.

85. Dockery D, Pope CI, Xiping X, Spengler J, Wore J, Fay M, ferris B, Speize, F. An association between air pollution and morality in six US cities. New England Journal of Medicine 1993; 329(24): 1753-1759.

86. Touloumi GI, Samoli E, Katsouyanni K. Daily mortality and winter type air pollution in Athens, a time series analysis within the APHEA Project. Journal of Epidemiology and Community Health 1996; 50(S1): S47-51.

87. Dab W, Medina S, Quenel P, Moullu YL, Tertre AL, Thaot B, Monteil C, Lamelaise P, Pirard P, Momar I, Ferry R, Festy B. Short term respiratory health effects of ambient air pollution result of the APHEA project in Paris. Journal of Epidemiology and Community Health 1996; 50(S1): S42-S46.

88. Spix C, Heinrich J, Dockery D, Schwartz J, Volksch G, Schwinkowski K Collen C, Wichman HE. Air 
pollution and daily mortality in Erfurt, East Germany, 1980-89. Environmental Health Perspective 1993; 101: 518-526.

89. Sunyer J, Castellsagul J, Saez M, Tobias A, Anto JN. Air pollution and mortality in Barcelona. Journal of Epidemiology and Community Health 1996; 50(S1): S76-S80.

90. Ostra B, Sanchez JM, Arada O, Eskeland G. Air Pollution and Mortality: Result from a study of Santiago, Chilli. Journal of Exposure Analysis and Environmental Epidemiology 1996; 6(1): 97-114.

91. Chestnut LG, Ostro BD, Vichit VN, Smith KR. Health effects of particulate matter air pollution in Bangkok. 1997; Draft final report, Feb 28.

92. Xu P, Gao J, Doekery DW, Chen Y. Air pollution and daily mortality in residential areas of Beijing. China Archives of Environmental Health 1994; 49(4): 216-222.

93. Cropper ML, Simon NB, Alberini A, Sharma PK. The effect of air pollution in Delhi, India. 1997; HandleRePEc:fth:wobaco: 1860.

94. Laden F, Neas LM, Dockery DW, Schwartz J. Association of fine particulate matter from different sources with daily mortality in six U.S. cities. Environ Health Perspect 2000 Oct;108(10):941-947

95. Bacharova L, Fandakova K, Bratinka J, Budinska M, Bachar J, Gudaba M. The association between air pollution and the daily number of deaths: finding from the Slovak republic contribution to the APHEA project. Journal of Epidemiology Community Health 1996; 50(S1): S19-S21.

96. Wojtyniak, Bogdan, Piekarski T. Short term effect of air pollution on mortality in Polish urban populationWhat is different?. Journal of Epidemiology \& Community Health 1996; 50(S1): S36-S41.

97. Zmirou D, Barumandzadeh T, Balducci F, Ritter P, Laham G, Ghilardi J P. Short term effect of air pollution on mortality in the city of Lyon, France. Journal of Epidemiology \& Community Health 1996; 50(S1): S30-S35.

98. Koren SK. Associations between criteria air pollutants and asthma. Environmental Health Perspectives 1995; 103(6): 235-242.

99. Bascom R, Bromberg P, Costa D, Devlin R, Dockery D, Frampton M, Lambert W, Samet J, Speizer F, Utell M. Health effects of out door air pollution. Am. J. Crit. Care Med. 1996; 153: 03-50.

100.Gold DR, Damokosh AI, PopeIII CA, Dockery DW, McDonnell W F, Serrano P, Retama A, Castillejos M. Particulate and ozone pollutant effects on the respiratory function of children in Southwest Mexico City. Epidemiology 1999;10: 8-15.

101.Bruce N, Perez-Padilla R, Albalak R. Indoor air pollution in developing countries: a major environmental and public health challenge. Bull World Health Organ 2000;78(9):1078-1092

102. Central Pollution Control Board (CPCB). National ambient air quality statistics of India 1992. Parivesh Bhavan, Delhi 1994-95.

103. Central Pollution Control Board (CPCB). National ambient air quality status and statistics of India. Parivesh Bhavan, Delhi 1995-96.

104.Handzel Z. Effects of Evironmental pollutants on airways allergic inflammation and the immune response. Rev Environ Health 2000; 15: 325-336.

105.Fubine B, Mallo L, Giamello E. Free radical generation at the solid/ liquid interface of iron- containing minerals. Free Radical Research 1995; 23: 593-614.

106.Gilmour PS, Brown DM, Lindsey TG, Beswick, PH, MacNel W, Donaldson. Adverse health effects of PM10 particles: involvement of iron in generation of hydroxyl radicals. Occup. Environmental Medicine 1995; 53: 817-822,

107. Carter JD, Ghio AJ Samct JM, Develin RB. Cytokines production by human airway epithelial cells after exposure to an air pollution particle is metal-dependent. Toxical. Pharmacol. 1997; 146: 180-188.

108. Osier N, Oberdorster G. Intracheal inhalation versus Intracheal Instillation: difference in particle effects. Fundamental Applied Toxicology 1997; 40: 220 -227.

109.Pope CA 3rd. Epidemiology of fine particulate air pollution and human health: biologic mechanisms and who's at risk? Environ Health Perspect 2000 108: 713-723

110.Rosenkranz HS. Mutagenic Nitro amines, Diesel Emissions, Particulate- Induced mutations and Cancer causations by a moving target. Mutation Research Genetic Toxicology 1996; 367(2): 65-72. 
111.Berube KA, Jones TP, Williamson BJ, Winters C, Morgan AJ, Richards RJ. Physico chemical characterization of diesel exhaust particles: factor for assuming biological activity. Atmospheric Environment 1999; 33 : 1599 1614.

112.Gerde P, Muggenburg BA, Lundborg M, Dahl AR. The rapid alveolar absorption of diesel soot-adsorbed benzo[a]pyrene: bioavailability, metabolism and dosimetry of an inhaled particle-borne carcinogen. Carcinogenesis 2001 May;22(5):741-749

113. Scientific Review Panel (SRP, USA). Findings of the Scientific Review Panel on the Report on diesel Exhaust as adopted at the Panelis, 22 April, 1998 meeting, California Resources Board, 1998; Mimeo.

114.Nielsen T, Jorgensen HE, Larsen JC, and Poulsen M. City air pollution of polycyclic aromatic hydrocarbons and other mutagens: occurrence, sources, and health effect. The Science of the Total Environment , 1996; 189190: 41-49.

115.Bruske-Hohlfeld I, Mohner M, Pohlabeln H, Ahrens W, Bolm-Audorff U, Kreienbrock L, Kreuzer M, Jahn I, Wichmann HE, Jockel KH. Occupational lung cancer risk for men in Germany: results from a pooled casecontrol study. Am J Epidemiol 2000 Feb 15;151(4):384-395.

116.Ross JA, Nesnow S. Polycyclic aromatic hydrocarbons: correlations between DNA adducts and ras oncogene mutations. Mutat Res 1999 Mar 8;424(1-2):155-166

117.Georgiadis P, Topinka J, Stoikidou M, Kaila S, Gioka M, Katsouyanni K, Sram R, Autrup H, Kyrtopoulos SA.. Biomarkers of genotoxicity of air pollution (the AULIS project): bulky DNA adducts in subjects with moderate to low exposures to airborne polycyclic aromatic hydrocarbons and their relationship to environmental tobacco smoke and other parameters. Carcinogenesis 2001 Sep;22(9):1447-1457.

118. Madhavan ND, and Naidu KA. Polycyclic aromatic hydrocarbons in placenta, maternal blood, umbilical cord blood and milk of India women. Human and Experimental Toxicology 1995; 14(6): 503-506.

119.Gladen BC, Zadorozhnaja TD, Chislovska N, Hryhorczuk DO, Kennicutt MC $2^{\text {nd }}$, Little RE.. Polycyclic aromatic hydrocarbons in placenta. Hum Exp Toxicol 2000; 19: 597-603.

120.Edwards R. Smog blights babies in the womb. New Scientist 1996; 152 (2052): 4.

121. Whyatt RM, Jedrychowski W, Hemminki K, Santella RM, Tsai WY, Yang K, Perera FP. Biomarkers of polycyclic aromatic hydrocarbon-DNA damage and cigarette smoke exposures in paired maternal and newborn blood samples as a measure of differential susceptibility. Cancer Epidemiol Biomarkers Prev 2001 Jun;10(6):581-588.

122. Schwela D. Air pollution and health in urban areas. Rev Environ Health 2000; 15: 13-42.

123. Needleman HL, Gatsonis CA. Low level lead exposure and the IQ of children: a meta- analysis of modern studies. JAMA 1990; 263:673-678.5

124.Goyer RA. Result of lead research: parental exposure and neurological consequences. Environmental Health perspectives 1996; 104(10).

125.Lundberg A. Psychiatric aspects of air pollution. Otolaryngol-head-Neck-Surg 1996; 114 (2). 